lead, it is suggested in the conclusion that the execution of the project's mission requires that reflection about the prospects of democratic socialism in the United States build upon a description and critique of the existing regime.

\section{DEWEY AND THE PROJECT OF CRITICAL SOCIAL THEORY}

Critical social theorists want to make history. They want their ideas to enlighten and motivate political mobilization for progressive social change. Committed to justice, liberty and democracy, critical theorists aspire to educate the political judgment of citizens seeking a fuller realization of these values in their societies. ${ }^{1}$ Considered historically, "in the broadest terms," writes Brian Fay, critical theory "is an attempt to understand ... the oppressive features of a society such that this understanding stimulates its audience to transform their society and thereby liberate themselves."2 Toward the end of Democracy and Capitalism Samuel Bowles and Herbert Gintis state that while their "project has been almost entirely theoretical, [their] intent is eminently practical: to forge tools to help understand the present trajectory of our societies and thereby to contribute to the possibility of a society of popular sovereignty and liberty."3

The focus of this paper is on the mission and structure of critical social theory. But clarifying its mission of educating citizens and identifying the components of critical theory qua theory is not sufficient to differentiate this project from opposing forms of social and political theory whose mission and structure are very similar. Three features differentiate critical theory from its rivals. First, an egalitarian conception to social justice is combined with a positive, developmental view of liberty as individual self-realization and a participatory notion of democracy. This is a value-orientation with historical roots in the Judeo-Christian and republican traditions, Kant, Rousseau, and romanticism. It is a value-orientation that finds diverse, more and less radical voices among Christian and utopian socialists, in Marx and John
Stuart Mill, in the Social Gospel, in the "new liberalism" of T. H. Green, J. A. Hobson, and Herbert Croly, and in various members of the Frankfurt School. The second feature of critical theory is the conviction that capitalism and the culture it produces do not and cannot support this value-orientation. Finally, critical theorists have commonly argued that only some form of democratic socialism is compatible with justice, liberty, and democracy properly understood. These last two features, and the theoretical and historical analyses upon which they rest, differentiates critical theory from progressive liberalism however much they share in the way of moral and political values. ${ }^{4}$

Success in the education of citizens is constrained by factors external and internal to critical social theory. External factors include the receptivity of its audience and any psychological, ideological, or other cultural impediments that must be overcome in order for the message to be received, understood, and found persuasive. Equally important is the power of political opponents to dominate not only the media, but also the institutional sites of political education and deliberation. No less significant is the privileged access enjoyed by the opposition to the economic and organizational resources of the state that could be used to steer society toward a more desirable future. All of these factors are beyond the capacity of the theorist qua theorist to control.

By contrast, factors internal to critical social theory can be controlled, and it is with these factors that this paper is concerned. The reference, here, is to the philosophical, social scientific, and imaginative dimensions of critical theory. Indeed, these dimensions and their interrelations are definitive of critical theory as a global, holistic enterprise transcending disciplinary boundaries. As such it is continuous with a tradition of "practical philosophy" with roots traceable to Plato and especially Aristotle. ${ }^{5}$ Recognizing this continuity, Seyla Benhabib maintains "the project of critical social theory [is] situated between practical philosophy and social science, sharing and radically reformulating the intentions of both." 
Since the realization of its moral and political objectives depends not only on the removal of external impediments but also on the reasonableness of these philosophical, scientific, and imaginative dimensions, we need to briefly clarify what the latter include. These dimensions, I suggest, can be further differentiated into five aspects: theory, description, critique, vision, and metatheory. In the following synopsis, I want to briefly sketch the meaning of each of these aspects. My purpose is not to break new ground or to defend a particular position, but rather to construct a conceptual map on which to locate the problems I want to address.

\section{The Project of Critical Social Theory}

Whether the task is understanding the "oppressive features of [our] society" or its "present trajectory", critical social theory must construct and defend a general conception of technologically advanced, liberal democratic societies-a theory of how they are structured and reproduced. Because the impediments to a more complete realization of justice, liberty, and democracy in these societies are linked, in part, to economic and class-based mechanisms of distributing wealth and power, critical theorists have frequently relied on a theory of capitalism-its genesis, periodization, crisis proneness, and developmental tendenciesto understand and explain how these mechanisms work and the role they play in liberal democracies. But there are other, deepseated, impediments based on racial prejudice, gender stereotypes, and a variety of other conventional beliefs, and values. The task of theory is not only to grasp the nature and institutionalization of these beliefs and prejudices, but also to articulate the linkages between these impediments and those based on differential access to economic, political, and cultural resources associated with the (social) class structure. A further task is to understand how world-views, ideals and wants are acquired and how they may be self-consciously and freely changed. This latter task requires theories of self, moral development, popular culture and education broadly conceived.

Necessary as theory construction is for orienting reflection on contemporary societies and the various impediments to equal opportunities for self-realization, it is not sufficient. At some point, the critical theorist must reach beyond the collegial circle of sympathetic intellectuals and address a public of fellow citizens who share with the theorist a common history and a common future. In the words of C. Wright Mills, the theorist must honor a "principle of historical specificity" by clarifying the "public issues" in her society and by illuminating the typical "personal troubles" among its members. ${ }^{7}$ As Mills insisted, clarification and illumination requires not only persuasive description, the second aspect of critical theory, but also looking at present issues and troubles from a distance-a reflective distance built upon an understanding of a specific nation's history and an analysis of its sociological and psychological deep structure. Of course this holistic investigation, like all empirical investigation, is guided by theory explicit or implied; but the focus of this aspect is descriptive. The interest, here, is not a general theory of "late capitalism," but rather a description of the present stage of capitalism in the United States or the Federal Republic of Germany, or some other country; not the plight of the post-modern self, but the situation of contemporary Italian women or members of the British underclass.

Theoretical and descriptive analyses contribute to the political intent of critical social theory by providing the knowledge and perspective necessary for the third aspect: critique. The latter is a many-sided appraisal of present society based on a commitment to justice, liberty, and democracy. The multiple forms of critique or appraisal can be divided into three types. One type is concerned with what may be called systemic rationality. Can present society reproduce itself without structural contradictions and institutional crises of one kind or another? Are its economic and political institutions of societal coordination and collective decision-making efficient and effective in the face of significant change in the political economy of the world? Such questions are 
clearly meaningless and unanswerable in the absence of theoretical and descriptive analysis.

A second type of criticism under various headings of "immanent critique," "defetishizing critique," and "Ideologieleritic," identifies existing social structural and ideological impediments which prevent or inhibit a fuller realization of justice, liberty, and democracy. ${ }^{8}$ Finally, a third type identifies developmental tendencies and possibilities pointing to alternative "trajectories" of contemporary societies into the future. The question is: Which of these possible futures holds the greatest promise for a more complete institutionalization of these values? Bowles and Gintis speak for most critical theorists when they argue that the moral and political objectives of critical social theory "will come to fruition, if at all, not through the substitution of the unprecedented for the familiar, but in the transformation of the present and in the development of structures and meanings already prefigured in today's society and discourse."

Critique, I said, is based on commitment to justice, liberty, and democracy. But commitment, here, is not to abstract, transhistorical ideals however reasonably defined. Commitment implies conceptions of justice, liberty, and democracy that build upon an appropriation of culturally indigenous moral, political, and philosophical traditions. ${ }^{10}$ It also implies a more or less articulate vision of the economic, political, and educational institutions necessary for these historically rooted ideals to be realized and reproduced; that is, it implies a rather explicit model of a good society based upon existing developmental possibilities and the appropriated value orientation. Political vision, in this sense, according to Sheldon Wolin, is "essentially architectonic." It constitutes the imaginative dimension of critical theory and one of its principal links with the classical tradition of practical philosophy. In its work of constructing normative institutional models, political vision reveals the meaning of justice, liberty, and democracy, providing, as it were, the normative standards for criticizing present society and evaluating the alternative developmental paths that lie before it. ${ }^{11}$
In specifying the theoretical, descriptive, critical, and visionary aspects of critical social theory, it is imperative not to lose sight of its moral and political objectives. Seyla Benhabib's statement of these objectives is typical. Critical theory, she writes,

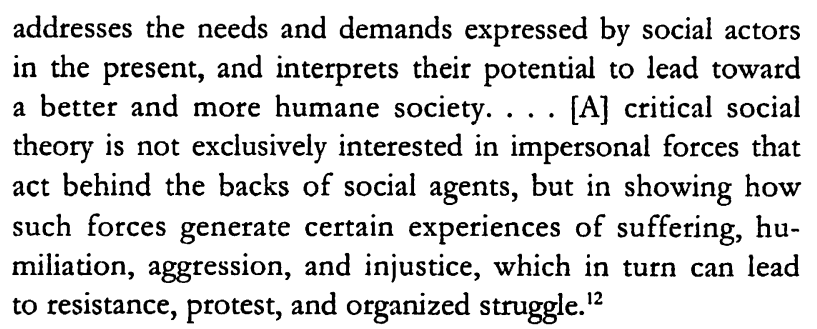

Benhabib reduces to two the four aspects of critical theory I have defined. She calls them the "explanatory-diagnostic' and "anticipatory-utopian" aspects. The purpose of the first is "crisis diagnosis;" i.e., the provision of an analysis of "the contradictions and dysfunctions of ... present [society]" and an explication of "the protests and pathologies-as the case may be-which they give rise to in the population." The anticipatory-utopian aspect "constitutes the more properly normative [dimension] of critique." Crisis diagnosis is always carried out "in the name of a better future and a more humane society." In other words, "critical social theory views the present from the perspective of the radical transformation of its basic structure, and interprets actual, lived crises and protests in light of an anticipated future."13 While I am sympathetic to Benhabib's analysis, I believe that meeting the practical objectives of critical theory requires addressing the "needs and demands" of individuals and groups in bistorically specific situations. This means that at some point critical theory must describe and criticize existing societies at a fairly concrete level of abstraction-a level on which cultural and political features that are definitive of particular societies are relevant to the critical analysis because they are constitutive of their members as citizens. Critical theorists may need a theory of the "life-world" as Benhabib following Habermas insists; but they also need empirically accurate, descriptive analyses of historically specific life-worlds-hence 
our differentiation of theory and description. Benhabib states that the anticipatory-utopian aspect of critical theory embraces the attempt "to rationally articulate a more adequate form of human existence." ${ }^{\prime 4}$ I think that such exercises in political imagination should be differentiated from the various types of critique-hence my differentiation of the critical from the visionary aspects of critical theory.

If a given society-how it is structured, how it came to be, its problematic features, and its future-is the subject of theory, description, critique, and vision, then the subject of metatheory is the project of critical social theory itself. Metatheory is the reflexive, "self-referential" aspect of critical theory. ${ }^{15}$ Among its tasks is the clarification and defense of the moral commitments and political objectives of the project as a whole. None of its tasks is more essential. Not only do theory construction and description (and more obviously, critique and vision) presuppose a relation to ideals and values-what Weber called "value-relevance"-but also the choice among alternative theories may reasonably depend upon value commitments as well. ${ }^{16}$ In addition to defending particular conceptions of justice, liberty, and democracy, therefore, the critical theorist as metatheorist must fully clarify the implication of these commitments for the other aspects of critical theory. ${ }^{17}$ No less important, however, is the additional metatheoretical task of answering the criticism and exposing the weaknesses of opposing currents of philosophy, ethics, political philosophy, and social science.

Another metatheoretical task is to examine the role critical theory ought to play in progressive social change. The focus here is upon the role of the message rather than the messenger. Whether there is a political role for critical theorists as intellectuals apart from their vocation as theorists is another question. ${ }^{18}$ In addition, metatheory must consider who the principal addressees are and how their needs, hopes, and desires constrain the articulation of theory, description, critique, and vision. ${ }^{19}$ Finally, metatheory is concerned with the identification of the conditions (social, political, and cultural) under which the message of critical theory is most likely to be ac- ceptable and politically motivating to its audience. ${ }^{20}$ In all of these tasks critical social theory (and its history) becomes an object to itself utilizing tools forged to explain, diagnose, and criticize contemporary society in order to determine its own possibilities and prospects as an emancipatory project.

\section{The Trouble With Critical Social Theory Today}

Among intellectuals committed to this project, there has evolved an informal and spontaneous division of labor. For whatever reasons-academic credentialing, professional demands, individual talent, and personal interests-committed intellectuals tend to specialize or at least concentrate their published work in one or two of the five aspects of critical theory. This division of labor makes for a diverse body of literature in several disciplines.

Diversity is not in itself troublesome, but it can be problematic. There is a tendency for the disciplinary fragmentation within higher education to be replicated in the "community" of critical theorists. Those who focus on the descriptive aspects of political economy and historical sociology normally leave to "philosophers" the tasks of metatheory and vise versa. Consequently, the ostensibly global, holistic project of critical theory tends to disintegrate into a loosely affiliated set of specialties. Moreover, despite a common commitment to roughly identical political ideals and objectives, the differences in philosophical and theoretical orientations are significant. Some orientations manifest a less problematic relation to the exercise of political judgment (and to political action) than do others. In some cases, the connection of this literature to the moral and political intentions that presumably drive its production is not clear.

The problematic conditions of the project of critical social theory raises several questions: (1) Is contemporary critical theory a source of existential and political enlightenment sufficient to motivate and encourage citizens to participate in movements for progressive social 
change? (2) Does the literature now being produced serve adequately the practical intention of enlightenment and motivation ${ }^{21}$ (3) How might the tendency toward the fragmentation of critical theory be overcome?, or, How might the task of integration required by an apparently inevitable specialization within critical theory as a collective project be accomplished?

Fully addressing these questions is beyond the scope of this essay and, perhaps, the capacity of any single paper. Maybe the time has come for another book like Gouldner's The Coming Crisis of Western Sociology-only this time a sociological analysis and immanent critique of critical social theory rather than the discipline of sociology. ${ }^{22}$ In any case, I raise these questions because I am disturbed by the internal specialization and fragmentation, and because the first two questions articulate as problems the anxiety I suspect to be widespread about the condition and future of critical theory particularly in the United States.

Despite signs of intellectual vitality - the international, interdisciplinary impact of Habermas, numerous journals, endless exegesis of Marx and western Marxism, on-going debate with neoconservatives and post-modernists-there is a pressing need for self-criticism. Amid these signs of health, the citizens whose needs, fears, and political confusion are theorized are little more than abstractions. Indeed, the intended audience of much of these examples is not really the public audience whose emancipation is the raison'd'etre of critical social theory. The intended audience is the "community" of professional and independent intellectuals. As a result, the moral and political objectives of critical theory are reduced to pious regulative ideals.

At the level of metatheory, a principal vehicle of self-criticism, insufficient attention has been paid to what the constituent elements of a process of popular enlightenment and motivation are. Insufficient thought has been devoted to an identification of the appropriate institutional sites for this process. Given a determination of the so- cial and psychological conditions of enlightenment and motivation, too little reflection has been expended on the implication of these conditions for theory construction, on what Mills called "intellectual craftsmanship" and historian James Henretta calls "rhetorical strategy," and on the most appropriate media of public presentation. ${ }^{23}$

If anxiety about the present state of critical theory is warranted, what must be done? The question is clearly premature in the absence of a general recognition among sympathetic intellectuals that serious problems of the kind suggested exit. Moreover, any program for the recovery of critical social theory ought to evolve from the collaboration of all who are interested in the revitalization of this project. To complicate matters, these conditions of general recognition and collaboration presuppose an infrastructure of organization and communication networks that does not exist.

And yet the anxiety persists and a response cannot wait until an appropriate infrastructure is created. I have in mind two proposals of which only one will be developed in this essay. The other would require a companion piece. Both proposals are metatheoretical in that each suggests a way of redirecting the project of critical theory. Together they focus on the internal relations-the mutual constraints and necessary coherence-between the moral commitments and political objectives of critical theory on one hand, and its five aspects on the other.

The first proposal-the one to be developed in a companion piece-suggests that theory, description, critique, and vision should proceed at a more concrete and neglected level of abstraction I call regime analysis. Here the object of theory, description, critique, and vision is a specific society (or nation-state) as a totality with its own history, institutional features, and cultural identity. Clearly, there are other social formations at more general levels of abstraction with which critical theorists have been traditionally concernedcapitalism, modernity, and the welfare state come to mind. Theories 
of these entities are essential for the study of individual regimes. But theorization of these entities often abstracts from the definitive features of particular countries and an exclusive concern for doing critical theory at this transnational level of abstraction inhibits the kind of dialogue between theorist and indigenous traditions of moral and political discourse that is essential for addressing an audience in a specific place. Moreover, theory-building has neglected historical analysis. Most theorists, it is true, recognize that capitalism has a history with stages or phases of development. ${ }^{24}$ What is missing are the national differences which can only be demonstrated through comparative and historical analyses sensitive to definitive institutional and cultural features. ${ }^{25}$

Regime analysis has two tracks-one descriptive, the other normative. The first track produces an examination of the institutional contours of an existing regime. It will, of necessity, draw upon the resources of historical sociology and cultural history. ${ }^{26}$ While the analysis strives for empirical accuracy, it is obviously not valueneutral because the whole purpose is to highlight those aspects of the regime that are problematic from the moral and political perspective that drives the research and critical interpretation. The second track is the work of the visionary aspect of critical theory. Here the purpose is to envision a desirable and feasible regime toward which the existing regime could be moved by political intervention as well as institutional design and reconstruction. Stephen Elkin calls this exercise in political imagination, "good society analysis." 27 Neither Elkin nor I, however, proposes a free-floating imagination. Instead, the work of good society analysis is disciplined by a moral and political standpoint that is itself a critical appropriation of cultural traditions indigenous to the existing regime. Repeating the words of Bowles and Gintis, the desired regime "will come to fruition, if at all, not through the substitution of the unprecedented for the familiar, but in the transformation of the present and in the development of structures and meanings already prefigured in today's society and discourse."28
Like the first, the second proposal would have the effect of making more immediate the connections between theorists and their own societies without loss of critical distance. Here the focus is upon those features of the project that establish a purchase on the significance and existential meaning of contemporary social change. These features bear a family resemblance to those of a broader and more ecumenical conception of social theory. In a recent essay, for example, Jeffrey Alexander has emphasized the "interpenetration of science and ideology in social theory." Social theory, Alexander states, not only explains the social world, it also interprets it; and theory interprets this world "in a manner that provide[s] 'meaning and motivation'." 29 The ideological dimension provides grounding for the interpretive work. The assumption is that there is a need for "meaning"- a need, that is, for intellectual and moral coherence in the face of the insecurities, uncertainties, risks, cultural pluralism, and political differences that define human existence in contemporary advanced societies. In a similar vein, Fred Block has written that

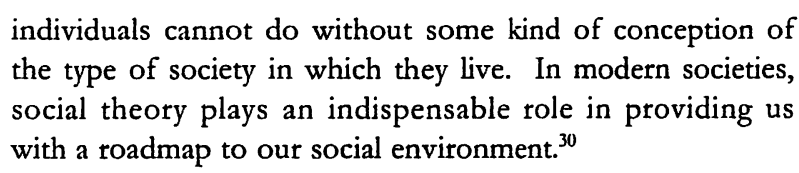

The roadmap, however, is not only conceptual in the sense of providing a vocabulary for understanding the structural and cultural features of contemporary society. The roadmap of critical social theory is also animated by a moral and political perspective-a substantive view of the meaning of liberty, justice, and democracy. It is this perspective that establishes a purchase on the moral and political significance of contemporary social change. Regarding the project of good society analysis-the visionary track of regime analysis-I stated that this perspective (or standpoint) is itself an appropriation of cultural traditions indigenous to the existing regime. The second proposal for reconstructing critical social theory, then, is to align it with a defensible form of historicism. ${ }^{31}$ I believe that American pragmatism, particularly the moral and political philosophy of John Dewey, provides a reasonable point of de- 
parture. Building upon this legacy could restore the linkage between the telos and the practice of critical theory.

The following section outlines Dewey's understanding of the mission of philosophy and how that mission might contribute to a reconstruction of American society in a desirable direction. In order to fulfill its mission, Dewey argues, philosophy must practice a type of cultural hermeneutics-a practice that puts Dewey squarely in the historicist camp. ${ }^{32}$ Moral and political philosophy becomes thereby a form of critical social theory whose purpose is to interpret for citizens and communities the implications and consequences of social change.

In the conclusion I return to the proposal for regime analysis. I suggest that a critical theory that builds upon the reflexive historicism inherent in Dewey's pragmatisim requires both tracks of regime analysis. I do not claim that Dewey was himself a theorist of the American regime in any systematic way; nor do I claim that Dewey engaged more than suggestively in the visionary project of institutional design or good society analysis. However, his impatience with concepts of "society in general," his recognition of the moral significance of institutions as they "operate under given conditions of definite time and place," and his insistence upon "substituting inquiry into ... specific, changing, and relative facts (relative to problems and purposes, not metaphysically relative) for . . . manipulation of general notions," suggest the level of abstraction and historical specificity upon which theoretical and descriptive analyses of existing regimes should proceed. ${ }^{33}$ By examining and clarifying regime-specific traditions of moral and political discourse, and by disclosing immanent possibilities of progressive social reconstruction in existing institutions, regime analysis of the first track prepares the ground and provides the materials necessary for social criticism and the disciplined projections of political imagination. Dewey's historicism-what James Kloppenberg calls his "historical sensibility"- provides the founda- tion for both examining the existing regime and designing a desirable and feasible one. ${ }^{34}$

\section{Jobn Dewey: Toward a Recovery of Critical Social Theory}

Two sources from the middle of Dewey's lengthy career provide a helpful beginning. In both "The Need For A Recovery of Philosophy" (1917) and Reconstruction in Philosopby (1920), Dewey is concerned about the kind of relationship that should exist between philosophers and the socio-economic and intellectual milieu in which they work. In both pieces (though more explicitly in the later one) he is acutely conscious of the recent transition in the United States from a segmented, decentralized, and agrarian political economy to one that is more interdependent, pluralistic, and increasingly based on applied science and large organizations. His message is critical and programmatic. The project of philosophy has become irrelevant beyond the circle of professional practitioners. Philosophy, Dewey argues, lacks clear purpose; it has lost touch with its constantly changing milieu. Philosophers, therefore, must reconstitute their project if the latter is to contribute to a humane and progressive reconstruction of their societies in response to recent economic, scientific, and institutional developments. Those interested in restoring the connection between the purpose and practice of critical social theory should consider what Dewey had to say:

Philosophy recovers itself when it ceases to be a device for dealing with the problems of philosophers and becomes a method, cultivated by philosophers, for dealing with the problems of men. ... There are human difficulties of an urgent, deep-seated kind which may be clarified by trained reflection, and whose solution may be forwarded by the careful development of hypotheses. When it is understood that philosophic thinking is caught up in the actual course of events, having the office of guiding them towards a prosperous issue, problems will abundantly present themselves. Philosophy will not solve these problems; philosophy is vision, imagination, reflectionand these functions, apart from action, modify nothing and hence resolve nothing. But in a complicated and perverse world, 
action which is not informed with vision, imagination, and reflection is more likely to increase confusion and conflict than to straighten things out. ${ }^{35}$

The scope of "human difficulties" and "problems" Dewey thought philosophy should address is broad. Borrowing from C. Wright Mills, they range from the typical "personal troubles" of individuals caused by threats to security and cherished values, to "public issues" springing, as Dewey states, "from a clash of social ends and from a conflict of inherited institutions with incompatible tendencies." ${ }^{\text {36 }}$ Whether problems be individual or social, Dewey argues, philosophy should draw on the resources of "all the disciplines which have an intimate connexion with human conduct." 37

The range of problems philosophy should address is further clarified by viewing Dewey's position in connection with an assertion by Max Weber:

Not ideas, but material and ideal interests, directly govern men's conduct. Yet very frequently the 'world images' that have been created by 'ideas' have like switchmen, determined the tracks along which action has been pushed by the dynamics of interests." 38

Like Weber, Dewey recognized the inevitability of conflicting interests (material and ideal) resulting from historically specific patterns of social stratification. ${ }^{39}$ Such conflicts are exacerbated by social change. As a result, for Dewey, philosophically significant problems emerge when cultural and institutional change threatens the satisfaction of material needs among the many, the structure of power dominated by elites, and the interest of all in justice and liberty. Problems also emerge when change makes obsolete for many people the inherited and largely religious world-views that construe "the world order in its totality ... [as] a meaningful 'cosmos."'40

Confronted with threatened and often conflicting material and ideal interests "the task of future philosophy," Dewey writes, "is to clarify men's ideas as to the social and moral strife of their own day. Its aim is to become so far as is humanly possible an organ for dealing with these conflicts." ${ }^{\prime 41}$ The range of social, moral, and political problems generated by conflicting interests and exacerbated by continuous social change defined the scope of personal troubles and public issues. But modern philosophy, appropriately reconstructed, has another (but related) task besides that of cultivating "vision, imagination, and reflection" among those who would address these problems.

Saddled with obsolete beliefs about nature and society, the task of philosophy is both critical and constructive. On one hand, it ought to become "a critique of prejudices, [or] . . . a critique of basic and widely shared beliefs." 42 Recognizing that "traditional beliefs ... are interwoven with institutional life in its diverse forms" and that such beliefs "sustain institutions and give them their hold on human loyalty and purpose," an indispensable task of philosophy "is criticism of beliefs, institutions, customs, [and] policies with respect to their bearing upon good." ${ }^{43}$ Moreover, since belief "always involves valuation, [or] preferential attachment to special types of objects and courses of action," and since beliefs and valuations "are intimately attached to customs and institutions, partly as effects, partly as causes, so that forces which impinge upon institutions and tend to unsettle them have a disturbing impact upon beliefs," it is clear to Dewey that "the most important shocks and inherent troubles of complex and changing societies ... have to do with conflicts of value." ${ }^{\prime 4}$ Philosophy, therefore, in becoming a criticism of beliefs becomes also a criticism of values and valuation in the various institutional spheres of human experience. ${ }^{45}$

Philosophy as criticism prepares the ground for its own contribution to a reconstruction of culture necessitated by the "march of industrialism" and "the decline of the operative forces of old standards and ideals." 46 Analogous to the manner in which former world-views brought coherence to common beliefs, the vocation of contemporary philosophy is "to bring intellectual order [to] . . the confusion of beliefs" in modern societies caused by a "lack of adjustment between ideas and ideals inherited from an older culture and the 
dominating interests and movements of present civilization ...." Philosophy performs this task when it "explores the meaning of actual conditions and possibilities [for humane development] that inhere in them." ${ }^{47}$

Likewise, it performs this task when it "restate[s] . . the ideals or spiritual elements that have been contained in the religions, arts, literature, moralities, and polities of our traditional inheritance." The point is to appropriate and interpret values and ideals embedded in older traditions and even obsolete world-views "so that they bear an operative relation to the state of affairs through which they are realizable" in the modern world. "By the same movement of thought," Dewey continues, "existent conditions cease to be taken as fixed, changeable only by some external and accidental intrusion; they cease to be models and measures of conduct." ${ }^{48}$

Intellectual and institutional developments definitive of modernity impede these efforts. "Professionalism . . . overspecialization, and [the] division of interests, occupations, and goods" produce "a tendency" for the "scientific, industrial, political, religious, artistic, educational, [and] moral" dimensions of social life "to seek rigid, non-communicating compartments." In order to counteract these tendencies toward intellectual and social fragmentation and "petrification," philosophy should become a generalized medium of intercommunication, of mutual criticism through allaround translation from one separated region of experience into another. Thus philosophy as a critical organ becomes in effect a messenger, a liaison officer, making reciprocally intelligible voices speaking provincial tongues, and thereby enlarging as well as rectifying the meanings with which they are charged. ${ }^{49}$

Whether assisting in the intellectual integration of various spheres of human experience, exploring the significance of recent developments in science, the economy, and the state, or appropriating "precious values embedded in social traditions," contemporary philosophy must address a cultural void, a deficit in existential meaning, expanding at the same rate as the power of older world-views to inspire the intellect and imagination declines.

This deficit in meaning, this general ignorance of the societal implications of recent developments in science, technology, and the national economy was, for Dewey, only one aspect of a "crisis in contemporary culture." integrity of religiously grounded world-views were also responsible for the rigidity and ineffectiveness, under conditions of modernity, of premodern forms of societal integration. Based on custom, religious authority, coercion, and class domination, these forms of integration maintained and reproduced the status hierarchies, enclaves of exclusivity, and social immobility of traditional societies. Dewey criticized current manifestations of these forms of social rigidity from a moral point of view. But his criticism was also sociological. A permanent state of social change caused by a conjuncture of specialized knowledge, technological and organizational innovation in the economy, urbanization, international commerce and communications, and geographical mobility required more reflexive, flexible, and adaptable forms of societal integration. The latter were required for the sake of justice and individual liberty. But they were also required if political communities were to solve public problems and achieve a measure of control over their own futures.

Dewey's ideas of democracy, education, and planning were developed with these requirements in mind. Underlying these ideas of integrating and steering a pluralistic, interdependent, industrial society, as both a resource of interpretation and as a "working model," was the social practice of modern science. In experimental investigation, "collectively tested" and "cooperatively confirmed" by an open community of inquirers, Dewey believed he had discovered a method of addressing problematic situations in all spheres of human experience. In the intellectual and social history of science he thought he had found an immanent model of "organized inquiry," communication, and "cooperative intelligence"-a kind of collec- 
tive reflexivity analogous to the reflexivity of individuals-based on the ideals of "free expression," "full publicity," and "toleration of diverse views." Clearly, if modern democratic polities were to articulate and satisfy public needs, balance diverse interests, and exert some control over the pace and direction of social change, then they needed to be transformed, Dewey thought, into political communities of inquiry incorporating "an experimental social method." 51 Policies and plans should be construed as "working hypotheses" subject to review and revision in light of imagined and observed consequences. By integrating the method of "experimental action" into its private and public organizations, democratic societies would become "self-repairing" social orders "which did not wait for periodic breakdowns to amend [their institutions]."

It is common for theorists of democracy to recognize that the intelligence of a democratic polity depends upon the intelligence of its citizens-hence the importance of education. As the necessity of incorporating some form of national planning into the government became more apparent to Dewey during the depression years of the 1930s, the connections between democracy and education as modes of societal integration received a specific interpretation in his writings. The "need for a society in which experimental inquiry and planning for social ends are organically contained," Dewey argued, "is also the need for a new education. In the one case as in the other, ... there is required the cooperative use of intelligence on a social scale in behalf of social values." A reconstructed system of education would cultivate "the ability and the desire to think collectively [and] to engage in social planning conceived and conducted experimentally for the good of all." Of course this particular task of education was only part of the larger mission of developing "habits," "attitudes," "purposes," and powers of communication which were "pertinent to the present scheme of social relationships, with its intricate and far-flung interdependencies among individuals" and which "enable[d] a democratic society to maintain itself, progressively and aggressively." 53
From both moral and sociological standpoints, therefore, there was a need for more reflexive, flexible, and adaptable forms of societal integration. But this need was only one aspect of the cultural crisis. The other aspect for Dewey, as I have shown, was the problem of meaning: the need to understand the significance for politics and society of recent developments in science and the economy, as well as the need to recover, reinterpret, and critically appropriate the values and ideals of our "national democratic tradition."54 Dewey's theories of democracy and education were also responsive to this other aspect of the crisis. In fact, for Dewey, resolution of the problem of meaning preceded the problem of integration in order of importance. Construed as planning and public problem-solving, democratic politics was parasitic upon continuing inquiry into the actual and potential consequences, desirable and undesirable, of modern institutional and intellectual developments. But the conduct of such inquiry-articulation of personal troubles, public problems, and planning objectives, as well as defending criteria of desirability-depended upon the meaning of the appropriated values and ideals to whose realization the machinery of government and the process of education were subordinate. ${ }^{55}$

The values and ideals to be revised and restated in light of modern conditions were democracy "as a way of life," liberty, equality, and community. ${ }^{56}$ The principal resource and starting point for this hermeneutical task of was the democratic republicanism of Thomas Jefferson. ${ }^{57}$ The "new version" of these ideals were to be integrated into a modern "social philosophy" expressing a distinct "moral outlook" and envisioning "a deliberately preferred social order" or regime. ${ }^{58}$ Dewey's complementary theories of democracy and education were examples of this kind of philosophy-actually, they were his contributions to a modern public philosophy for the nation. Given the inertia of antiquated habits and modes of thought, and given the power of the capitalist class to obstruct progressive change, Dewey knew that truly modern forms of democracy and education would not materialize automatically however reasonable they might be from moral and sociological points view. ${ }^{59}$ His own political activities and 
observations, particularly during the 1930 s, convinced Dewey that the institutionalization of the "preferred social order" depended upon political mobilization for the "radical" reconstruction of American culture and society. ${ }^{60}$

\section{Conclusion: Dewey and Regime Analysis}

I stated earlier that Dewey was not, strictly speaking, a regime theorist. He gives readers neither a detailed portrait of a good society nor a comprehensive historical and institutional description of the American regime. Nevertheless, there are embedded in his writings proposals for both normative and descriptive tracks of regime analysis. ${ }^{61}$ In "Philosophy and Democracy" (1918), articulating the contours of a good society is a project for philosophers:

[W] hat makes philosophy hard work and also makes its cultivation worth while, is precisely the fact that it assumes the responsibility for setting forth some ideal of a collective good life by the methods which the best science of the day employs in its quite different task, and with the use of the characteristic knowledge of its day. ${ }^{62}$

Setting forth such an ideal and describing the set of institutions that would be required to achieve it is an exercise in normative regime analysis. Throughout his career the label Dewey gives to his own ideal-to his own "view of a deliberately preferred social order"-is democracy; that is to say, democracy as a "way of life" rather than simply a form of government. ${ }^{63}$ Dewey insists, however, that his statement of this ideal is not merely a private preference, but rather a reasonable interpretation of core values in the American political tradition.

The purpose of normative regime analysis is to outline-however tentatively - the set of economic, social, and political institutions that can be expected to realize and embody the moral and political values of the "good life." At the end of Spheres of Justice (1983) Michael
Walzer sketches a regime that coheres with his own conception of justice as "complex equality":

a decentralized democratic socialism, a strong welfare state run, at least in part by local and amateur officials; a constrained market; an open and demystified civil service; independent public schools; the sharing of hard work and free time; the protection of religious and family life; a system of public honoring and dishonoring free of considerations of rank or class; workers' control of companies and factories; a politics of parties, movements, meetings, and public debate. But institutions of this sort are of little use unless they are inhabited by men and women who feel at home within them and are prepared to defend them. ${ }^{64}$

Dewey would have endorsed Walzer's sketch. But nowhere in Dewey's writings is there a summary like Walzer's to be found. What can be found are statements in which Dewey positions his democratic socialism-what he call "liberal socialism"-to the left of the New Deal, but clearly continuous with the liberal tradition. ${ }^{65}$ Absent in Walzer's sketch, but present in Dewey's sometimes cryptic projections, is the idea of planning - an idea that is not totally incompatible with markets. ${ }^{66}$ However, whether the subject is liberal socialism or planning, Dewey emphatically differentiates his methodology of regime analysis from orthodox Marxism and from the "authoritarian socialism" of the Soviet Union. ${ }^{67} \mathrm{He}$ was aware of the "danger ... that in ... get[ting] away from the evils of private economic collectivism ['state capitalism'] we [could] plunge into political economic collectivism ['state socialism']. ${ }^{\prime 68}$ Like Walzer's sketch we find statements in Dewey's writings to the effect that a democratic way of life requires a type of citizen whose character is shaped by democratic institutions and who, therefore, "feel[s] at home within them." Democratic socialism requires, according to Dewey, a "new individualism." But like the substance of this new type, Dewey is reluctant to give readers more than glimpses of what the institutional profile of democratic socialism is: "I am not anxious to depict the form which this emergent individualism will assume. Indeed, I do not see how it can be described until more progress has been made in its production." ${ }^{70}$ 
Discourse about a desirable future is not to be spun out of thin air. The case for its desirability-as well as its feasibility-has to be anchored in the cultural and institutional history as well as the developmental tendencies of the existing regime. A desirable future that is also socially, politically, and technologically possible must be immanent in the institutions and practices of the existing society. ${ }^{71}$ We do not start from scratch. Contemporary culture and institutions, clarified and criticized through the disciplined exercise of sociological imagination, provide the material out of which a desirable and feasible society can be created. The normative track of regime analysis, therefore, requires and builds upon the descriptive one. ${ }^{72}$

In two essays on the philosophy of education written with John L. Childs, Dewey argues that education broadly conceived should be informed not only by a view of the good life, but also by an accurate account of the existing regime. Any comprehensive philosophy of education remains formal and abstract [that] is not applied to some particular society existing at a definite time and place. Factors of time and place do not receive recognition as long as nominal social conceptions of education are not connected to the concrete facts of family, industry, business, politics, church, [and] science, in this country. If we are not to be content with formal generalities ... they must be translated into descriptions and interpretations of the life which actually goes on in the United States today for the purpose of dealing with forces which influence and shape it. ${ }^{73}$

These "descriptions and interpretations"- the historical and empirical track of regime analysis-should have "both a critical and constructive side." As an exercise in social criticism, they should expose and clarify ideologies, institutions and practices which undermine democracy and "the American tradition of equal opportunity" for individual self-realization. ${ }^{74}$ In Liberalism and Social Action (1935), for example, Dewey provides a history of laissez-faire liberalism as an ideological impediment to the creation of a democratic way of life. ${ }^{75}$ In Individualism, Old and New (1929-30) he argues that an increasingly money-driven, acquisitive culture has "obscured and crowded out . . . the spiritual factor[s] of our tradition, [namely,] equal opportunity . $\ldots$, free association and intercommunication . . . , and the development of individualities ...."76 In this earlier work there is a critique of the bureaucratic workplace. Managerial dictatorship and Tayloristic procedures stunt the intellectual and moral development of workers and consequently their growth as citizens. ${ }^{77}$ At the core of Dewey's social criticism in these two works and elsewhere is his belief that under the domination of a capitalist economy, and the elites who own and control it, American democracy has atrophied and "an abundant cultural development for all" has been thwarted. In Freedom and Culture (1939) Dewey states: "The idea of a pre-established harmony between the existing so-called capitalistic regime and democracy is as absurd a piece of metaphysical speculation as human history has ever evolved." 78

According to Dewey, however, the existing society cannot be reduced to its capitalist attributes. "It is simply false," he states, "that this country, even politically, is merely a capitalistic democracy." The purpose of the constructive side of descriptive analysis is to disclose those indigenous cultural, organizational, and technological resources that could be developed, redesigned, and used to subordinate production for profit to the common good, replace bureaucracy, and create a truly democratic society. In addition to democratic ideals associated with the names of Jefferson and Lincoln, Dewey argues in Liberalism and Social Action (1935), there is a strain of humanitarian liberalism more compatible with democracy than its laissez-faire counterpart, and rooted in romanticism rather than utilitarianism, that could be relied upon for moral and political guidance. ${ }^{80}$ There is also modern science and technology which, if it could be severed from its subservience to capitalism, could provide the material security necessary for equal access to the cultural resources necessary for individual self-development. ${ }^{81}$ As I indicated earlier, Dewey believed the practice of science, properly understood, could 
contribute both to the creation of a "planning," deliberately "selfrepairing" society, and to the formation of democratic, nonbureaucratic, learning organizations in the economy, government, and in society at large. Moreover, there was precedence for planning in the operation of not only of the War Industries Board during World War I, but also the largest corporations and financial institutions. $^{82}$

The constructive side of descriptive regime analysis discloses within the existing society the foundation upon which a desirable regime can be created. It provides the material for the exercise of political imagination, judgment, and institutional design that constitutes good society thinking. Driving both descriptive and normative tracks is a set of moral and political convictions. Social philosophy, Dewey maintains,

embodie[s] not colorless intellectual readings of reality, but men's most passionate desires and hopes, their basic beliefs about the sort of life to be lived. They start ... not from science, not from ascertained knowledge, but from moral convictions, and then resort . . to the best knowledge and the best intellectual methods available in their day to give the form of demonstration to what [is] essentially an attitude of will or moral resolution to prize one mode of life more highly than another, and the wish to persuade other men that this [is] the wise way of living. ${ }^{83}$

Dewey's commitment to democracy as a way of life was unwavering. So too was his commitment to individual freedom and equal opportunity for individual self-development-liberal ideals he believed were at the core of the American political tradition. ${ }^{84}$ These commitments and beliefs are necessary but insufficient conditions for placing Dewey in the company of critical social theorists. What really places him in this company are his judgments that capitalism and the culture it produces are the principal impediments to the realization of these ideals, and that the creation of some form of homegrown, democratic socialism is the appropriate path of deliberate social reconstruction.
What Dewey calls social or political philosophy, and actually produces in works like Individualism, Old and New (1929-30) and Freedom and Culture (1939), is, in fact, critical theory. There is the same integration of philosophical, social scientific, and imaginative dimensions. Nevertheless, the synthesis of descriptive and normative analyses, Dewey was clearly aware, differentiates his practice of social philosophy (or critical theory) from the social sciences upon which it relies, and from purely speculative utopian thought. ${ }^{85}$ Repeating the words of Seyla Benhabib, what we have in Dewey's political writings is a "project . . . situated between practical philosophy and social science, sharing and radically reformulating the intentions of both." ${ }^{\$ 86}$

\section{References}

Alexander, Jeffrey A. 1995. "Modern, Anti, Post, and Neo." New Left Review \#210 (March/April), pp. 63-101.

Antonio, Robert J. 1989. "The Normative Foundations of Emancipatory Theory: Evolutionary versus Pragmatic Perspectives." American Journal of Sociology 94 (January), pp. 721-48.

Beiner, Ronald. 1983. Political Judgment. Chicago: University of Chicago Press.

Bender, Thomas. 1986. "Wholes and Parts: The Need For Synthesis in American History." Journal of American History 73 June), pp. 120-36.

Benhabib, Seyla. 1986. Critique, Norm, and Utopia: A Study of the Foundations of Critical Theory. New York: Columbia University Press.

Bernstein, Richard J. 1983. Beyond Objectivism and Relativism: Science, Hermeneutics and Praxis. Philadelphia: University of Pennsylvania Press.

Best, Steven and Kellner, Douglas. 1991. Postmodern Theory: Critical Investigations. New York: The Guilford Press.

Block, Fred. 1990. Postindustrial Possibilities: A Critique of Economic Discourse. Berkeley: University of California Press.

Bowles, Samuel, and Gintis, Herbert. 1986. Democracy and Capitalism: Property, Community, and the Contradictions of Modern Social Thought. New York: Basic Books, Inc., Publishers.

Boyer, Robert. 1990. The Regulation School: A Critical Introduction. Translated by Craig Charney. Cambridge: Cambridge University Press. 
Breines, Paul. 1977. "Marxism, Romanticism, and the Case of Georg Lukas: Notes on Some Recent Sources and Situations." Studies in Romanticism 16 (Fall), pp. 473-89.

Cohen, Jean L. 1982. Class and Civil Society: The Limits of Marxian Critical Theory. Amherst: University of Massachusetts Press.

Collini, Stefan, Winch, Donald, and Burrow, John. 1983. That Noble Science of Politics: A Study in Nineteenth-Century Intellectual History. Cambridge: Cambridge University Press.

Corbin, Carol. Ed. 1998. Rhetoric in Postmodern America: Conversation with Michael Calvin McGee. New York: Guilford Press.

Dallmayr, Fred R. 1984. Polis and Praxis: Exercises in Contemporary Political Theory. Cambridge, MA.: The MIT Press.

Dewey, John. 1916. Democracy and Education: An Introduction to the Pbilosopby of Education. New York: The Free Press.

. 1917. "The Need For A Recovery of Philosophy," in Creative Intelligence, pp. 3-69. By John Dewey, Addison W. Moore, Harold Chapman Brown, George H. Mean, Boyd H. Bode, Henry Waldgrave Stuart, James Hayden Tufts, and Horace Kallen. New York: Henry Holt and Company.

- 1922(1957). Human Nature and Conduct: An Introduction to Social Psychology. New York: The Modern Library.

. 1920(1957). Reconstruction in Pbilosopby (Enlarged Edition). Boston: Beacon Press.

1927. The Public and Its Problems. Denver: Alan Swallow.

1929. The Quest For Certainty: A Study of the Relation of Knowledge and Action. New York: Capricorn Books.

1931. "Context and Thought," In Jobn Devey On Experience, Nature, and Freedom, pp. 88-110. Edited by Richard J. Bernstein. New York: The Liberal Arts Press.

1939a. Freedom and Culture. New York: Capricorn Press.

1939b. Theory of Evaluation. In International Encyclopedia of Unified Science,

Volume II, Number 4. Edited by Otto Neurath. Chicago: University of Chicago Press.

. 1940a. "Presenting Thomas Jefferson." In The Living Thoughts of Thomas Jefferson, pp. 1-30. Edited by John Dewey. New York: Longmans, Green and Co.

. 1940b. "Thomas Jefferson and the Democratic Faith." Virginia Quarterly Review 16 (January, 1940), pp. 1-13.

- 1976-83. The Middle Works, 1899-1924. Edited by Jo Ann Boydson. 15 volumes. Carbondale: Southern Illinois University Press.

1981-92. The Later Works, 1925-1953. Edited by Jo Ann Boydson. 17 volumes. Carbondale: Southern Illinois University Press.

Elkin, Stephen L. and Soltan, Karol Edward. Eds. 1993. A Nen Constitutionalism: Designing Political Institutions. Chicago: University of Chicago Press.

Esping-Andersen, Gosta. 1990. The Three Worlds of Welfare Capitalism. Princeton: Princeton University Press.
Fay, Brian. 1987. Critical Social Science: Liberation and Its Limits. Ithaca: Cornell University Press.

Festenstein, Matthew. 1997. Pragmatism and Political Theory: From Dewey to Rorty. Chicago: University of Chicago Press.

Fraser, Nancy. 1989. Unruly Practices: Power, Discourse, and Gender in Contemporary Social Theory. Minneapolis: University of Minnesota Press.

Galston, William H. 1980. Justice and the Human Good. Chicago: University of Chicago Press.

Gerth, H. H. and C. Wright Mills, trans., and eds. 1946. From Max Weber: Essays in Sociology. New York: Oxford University Press.

Geuss, Raymond. 1981. The Idea of A Critical Theory: Habermas and the Frankfurt School. Cambridge: Cambridge University Press.

Gordon, David M. 1996. Fat and Mean: The Corporate Squeeze of Working Americans and the Myth of Managerial "Downsizing". New York: Martin Kessler Books.

Gordon, David M.; Edwards, Richard; and Reich, Michael. 1982. Segmented Work, Divided Workers: The Transformation of Labor in the United States. Cambridge: Cambridge University Press.

Gouldner, Alvin W. 1970. The Coming Crisis of Western Sociology. New York: Basic Books, Inc..

1973. For Sociology: Renewal and Critique is Sociology Today. New York: Basic Books, Inc., chap. 2.

. 1980. The Two Marxisms: Contradictions and Anomalies in the Development of Theory. New York: Oxford University Press.

- 1985. Against Fragmentation: The Origins of Marxism and the Sociology of Intellectuals. New York: Oxford University Press.

Habermas, Jurgen. 1973. Theory and Practice. Translated by John Viertel. Boston: Beacon Press.

Hart, Jeffrey A. 1992. Rival Capitalists: International Competitiveness in the United States, Japan, and Western Europe. Ithaca: Cornell University Press.

Held, David. 1996. Models of Democracy. 2d ed. Stanford: Stanford University Press.

Hennis, Wilhem. 1988. Max Weber: Essays in Reconstruction. Translated by Keith Tribe. London: Allen \& Unwin.

Henretta, James A. "Social History as Lived and Written." American Historical Review 84 (December 1979), pp. 1293-1322.

Hesse, Mary. 1978. "Theory and Value in the Social Sciences." Action and Interpretation: Studies in the Pbilosopby of the Social Sciences. Edited by Christopher Hookway and Philip Pettit. Cambridge: Cambridge University Press, p. 1-16.

Hickman, Larry A. Ed. 1998. Reading Dewey: Interpretations for a Postmodern Generation. Bloomington: Indiana University Press.

Hollinger, David A. 1997. "How Wide the Circle of the 'We"? American Intellectuals and the Problem of the Ethnos Since World War II." Scientific Authority o Twentieth-Century America. Edited by Ronald G. Walters. Baltimore: Johns Hopkins University Press, pp. 13-31. 

James, Susan. 1984. The Content of Social Explanation. Cambridge: Cambridge Uni-
versity Press.

Kettler, David. "Sociology of Knowledge and Moral Philosophy: The Place of Traditional Problems in the Formation of Mannheim's Thought." Political Science Quarterly 82 (September, 1967), pp. 399-425.

Kloppenberg, James T. 1986. Uncertain Victory: Social Democracy and Progressivism European and American Thought, 1870-1920. New York: Oxford University
Press.

Kotz, David M.; McDonough, Terrence; and Reich, Michael; eds. 1994. Social
Structures of Accumulation: The Political Economy of Structures of Accumulation: The Political Economy of Growth and Crisis. Cambridge: Cambridge University Press.

Kumar, Krishan. 1995. From Post-Industrial to Post Modern Society: New Theories of the Contemporary World. Oxford: Blackwell. Lentricchia, Frank. 1983. Criticism and Social Change. Chicago: University of
Chicago Press.

Levitas, Ruth. 1989. "Marxism, Romanticism and Utopia: Ernst Bloch and William Morris." Radical Philosopby \#51 (Spring), pp. 27-36.

Livingston 1990. The Concept of Utopia. Syracuse University Press. 1850-1940. Chapel Hill. Unatism and the Political Economy of Cultural Revolution,

versity of North Carolina Press.

44 (Summer), pp. 25-33. 1987. "The Romantic

and Society volume 16, pp. $891-904$. Critique of Modern Civilization." Theory

Tandel Ernest 1975.

ate Capitalism. London: NLB.

1980. Long Waves of Capitalist Development: The Marxist Interpretation. Cam-

niversity Press.

View. Lawrence. 1984. The Radical Politics of Thomas Jefferson: A Revisionist View. Lawrence: University of Kansas Press. Mills, C. Wright. 1959. The Sociological Imagination. New York: Oxford University
Press.

1962. The Marxists. New York: Dell Publishing Co. New York: Oxford University Press.

Rorty, Richard. 1987. "Thugs and Theorists: A Reply to Bernstein" Political Theory 15 (November), pp. 564-80.

Sayre, Robert and Lowy, Michael. 1984. "Figures of Romantic Anti-Capitalism," New German Critique \#32 (Spring-Summer), pp. 42-93.

Shalin, Dimitri N. 1986. "Romanticism and the Rise of Sociological Hermeneutics." Social Research 53 (Spring), pp. 77-123.

Shapiro, Ian. 1990. Political Criticism. Berkeley: University of California Press.

Smith, Steven B. 1989. Hegel's Critique of Liberalism: Rights in Context Press. University of Chicago Press.

Soltan, Karol Edward and Elkin, Stephen L. Eds. 1996. The Constitution of Good 30
Stuhr, John J. Ed. 1993. Philosopby and the Reconstruction of Culture: Pragmatic Essays After Dewey. Albany: State University of New York Press.

Taylor, Charles. 1975. Hegel. London: Cambridge University Press.

Thompson, E. P. 1976. "Romanticism, Moralism, and Utopianism: the Case of William Morris." New Left Review \#99 (Sept.-Oct.), pp. 83-111.

Tillich, Paul. 1977. The Socialist Decision, trans. Franklin Sherman. New York Harper \& Row.

Toulmin, Stephen. 1988. "The Recovery of Practical Philosophy." The American Scholar 57 (Summer), pp. 337-352.

Walzer, Michael. 1983. Spheres of Justice: A Defense of Pluralism and Equality. New York: Basic Books, Inc. .

1985. Interpretation and Social Criticism. Cambridge, MA.: Havard University Press.

1988. The Company of Critics: Social Criticism and Political Commitment in The Twentieth Century. New York: Basic Books, Inc.

Weber, Max. 1949. The Methodology of the Social Sciences. Translated and Edited by Edward A. Shils and Henry A. Finch. New York: The Free Press of Glencoe

Westbrook, Robert B. 1991. John Dewey and American Democracy. Ithaca: Cornell University Press.

Williams, Raymond. 1958. Culture and Society: 1780-1950. New York: Harper Torchbooks.

Wolin, Richard. 1987. "Critical Theory and the Dialectic of Rationalism." New German Critique \#41 (Spring-Summer), pp. 23-52.

Wolin, Sheldon S. 1960. Politics and Vision: Continuity and Innovation in Western Political Thought. Boston: Little, Brown and Company.

Wood, Ellen Meiksins. 1972. Mind and Politics: An Approach to the Meaning of Liberal and Socialist Individualism. Berkeley: University of California Press.

\section{Notes}

${ }^{1}$ Of course the meaning of justice, liberty, and democracy is contested among intellectuals and the broader public. Prominent conservative liberals like Friedrich Hayek and Milton Friedman seek also to educate citizens in the name of these ideals. In their case, however, justice, liberty, and democracy bear a meaning fully compatible with free market capitalism. By contrast, critical theorists are sensitive to the tensions, if not incompatibility between capitalism in all its forms and the realization of these values when the latter are properly understood. Historically such sensitivity has led to advocating some form of social democracy, socialism, or communism. Broadly conceived, however, critical social theory is not bounded by Marxism or the Frankfurt School. It includes also the contributions of nonmarxists like G. D. H. Cole, R. H. Tawney, Lewis Mumford, John Dewey, Karl Polanyi, C. Wright Mills, and Michael Walzer.

2 Brian Fay, Critical Social Science (Ithaca: Cornell University Press, 1987) p. 4; cf., pp. 2, 23, 26, 28, 39, 205-06. 
${ }^{3}$ Samuel Bowles and Herbert Gintis, Democracy and Capitalism (New York: Basic Books, Inc., 1986) p. 184.

${ }^{4}$ It would take a book to defend this paragraph. As a feeble alternative, I will merely cite a few books and articles that lend credibility to the argument: Ellen Meiksins Wood, Mind and Politics: An Approach to the Meaning of Liberal and Socialist Individualism (Berkeley: University of California Press, 1972); Raymond Williams, Culture and Society: 1780-1950 (New York: Harper Torchbooks, 1958); Charles Taylor, Hegel (London: Cambridge University Press, 1975), chap. 1; James T. Kloppenberg Uncertain Victory: Social Democracy and Progressivism in European and American Thought, 1870-1920 (New York: Oxford University Press, 1986); Ruth Levitas, The Concept of Utopia (Syracuse University Press, 1990); David Held, Models of Democracy, 2d ed. (Stanford: Stanford University Press, 1996); Paul Tillich, The Socialist Decision, trans. Franklin Sherman (New York: Harper \& Row, Pub., 1977); Alvin W. Gouldner, For Sociology: Renewal and Critique in Sociology Today (New York: Basic Books, Inc, 1973), chap. 2; idem., Against Fragmentation: The Origins of Marxism and Sociology of Intellectuals (New York: Oxford University Press, 1985); Dmitri N. Shalin, "Romanticism and the Rise of Sociological Hermeneutics," Social Research 53 (Spring, 1986), pp. 77-123; E. P. Thompson, "Romanticism, Moralism, and Utopianism: the Case of William Morris," New Left Revien \#99 (Sept.-Oct., 1976), pp. 83-111; Paul Breines, "Marxism, Romanticism, and the Case of Georg Lukas: Notes on Some Recent Sources and Situations," Studies in Romanticism 16 (Fall, 1977), pp. 473-89; Michael Lowy, "Marcuse and Benjamin: The Romantic Dimension," Telos \#44 (Summer, 1980), pp. 25-33; idem., "The Romantic and Marxist Critique of Modern Civilization," Theory and Society 16 (1987), pp. 891-904; Robert Sayre and Michael Lowy, "Figures of Romantic Anti-Capitalism," New German Critique \#32 (Spring Summer, 1984), pp. 42-93.

${ }^{5}$ On the idea of "practical philosophy," see Fred R. Dallmayr, Polis and Praxis: Exerises in Contemporary Political Theory (Cambridge, MA: MIT Press, 1984) pp. 10, 41-45, 59-60, 72-73. Steven B. Smith recognizes the roots of Hegel's political theory in the tradition of practical philosophy in Hegel's Critique of Liberalism: Rights in Context (Chicago: University of Chicago Press, 1989) pp. 13, 132-40. In identifying the intellectual origins of Max Weber's sociology in the German Historical School of political economy, Wilhelm Hennis argues for the continuity between practical philosophy and Weber's project (see Max Weber: Essays in Reconstruction, translated by Keith Tribe (London: Allen \& Unwin, 1988) chap. 3. David Kettler positions Karl Mannheim in the same historical and political-theoretical context in "Sociology of Knowledge and Moral Philosophy: The Place of Traditional Problems in the Formation of Mannheim's Thought," Political Science Quarterly 82 (September, 1967) pp. 399-425. See also Ronald Beiner, Political Judgment (Chicago: University of Chicago Press, 1983); Richard J. Bernstein, Beyond Objectivism and Relativism: Science, Hermeneutics, and Praxis (Philadelphia: University of Pennsylvania Press, 1983) pp. 188-190; and Stephen Toulmin, "The Recovery of Practical Philosophy," The American Scholar 57 (Summer, 1988), pp. 337-52.

${ }^{6}$ Seyla Benhabib, Critique, Norm, \& Utopia: $A$ Study of the Foundations of Critical Theory (New York: Columbia University Press, 1986) pp. 2-3; her introduction 32 entitled " The Critical Theory of Society: Between Practical Philosophy and Social Science" is outstanding. An earlier recognition of the continuity of practical philosophy and critical theory appears in Jurgen Habermas, Theory and Practice, trans. John Viertel (Boston: Beacon Press, 1973), pp. 41-42.

7 C. Wright Mills, Sociological Imagination (New York: Oxford University Press, 1959), pp. 8-13, 129-31,149, 157, 163,177, 184-85, 187, 226; idem., Power, Politics, \& People, Edited and introduced by Irving L. Horowitz (New York: Oxford University Press, 1963), pp. 245, 253, 384, 395-402; idem., The Marxists (New York: Dell Publishing Co.: 1962), pp. 37-38.

${ }^{8}$ Raymond Geuss, The Idea of $A$ Critical Social Theory: Habermas and the Frankfurt School (Cambridge: Cambridge University Press, 1981), pp. 2-3, 55, 58-65, 68, 7076, 80-84, 87-88; Jean L. Cohen, Class and Civil Society: The Limits of Marxian Critical Theory (Amherst: University of Massachusetts Press, 1982), pp. 29-36, $43-$ 52, 148-49, 154-55, 164, 169-79, 180, 186-87, 191-92, 196, 224, 227; Benhabib, Critique, Norm, and Utopia (1986), pp. 7-9, 22-33, 45-55, 66-67, 105-08, 121-23, 153-54, 171-76.

' Bowles and Gintis, Democracy \& Capitalism (1986), p. 185 (my emphasis). Mills also emphasizes the importance of discerning developmental tendencies and possible trajectories: see The Sociological Imagination (1959), pp. 151-53, 174.

${ }^{10} \mathrm{I}$ am fully aware that these assertions about commitment appear to position my argument on the "contextualist" side of the contemporary debate in political theory between (foundationalist) liberalism and (contextualist or historicist) communitarianism. Among critical theorists this debate is reflected in the philosophical differences between the "quasi-transcendental" political ethics of Jurgen Habermas and the "connected criticism" of Michael Walzer. I believe a defensible form of naturalism and a view of inquiry that builds on the legacy of classical pragmatism, and John Dewey in particular, is able to steer a reasonable (and, for critical theory, an indispensable) course between the extremes in this debate. Steven Smith's opening chapter in Hegel's Critique of Liberalism (1989) provides a good introduction to this debate as does Ian Shapiro in Political Criticism (Berkeley: University of California, 1990). Shapiro's conception of "principled criticism" based on "critical naturalism" and "philosophical realism" is more friendly to classical pragmatism than it is to the neo-pragmatism of Richard Rorty. Robert Antonio defends Dewey's historicism against the transhistorical ethics of Habermas in "The Normative Foundations of Emancipatory Theory: Evolutionary versus Pragmatic Perspectives," American Journal of Sociology 94 January, 1989), pp. 721-48. In her friendly critique of Habermas's ethics Benhabib has argued that only concrete cultural traditions of specific societies can provide substantive content to political ideals like justice, liberty, and democracy. See Benhabib, Critique, Norm, and Utopia (1986), pp. 260, 262-63, 279, 288-98, 306, 319-22, 326, 335-36.

"Sheldon Wolin, Politics and Vision: Continuity and Innovation in Western Political Thought, (Boston: Little, Brown and Company: 1960), pp. 19-20. See also William Galston, Justice and the Human Good (Chicago: University of Chicago Press: 1980), pp. 14-15 and Benhabib, Critique, Norm, and Utopia (1986), pp. 4, 5, 7, 14, 142, 225- 
26, 324-34, 336-39, 352-53; Ruth Levitas, "Marxism, Romanticism, and Utopia: Ernst Bloch and William Morris," Radical Pbilosopby \#51 (Spring, 1989), pp. 27-36.

${ }^{12}$ Benhabib, Critique, Norm, and Utopia (1986), p. 226.

${ }^{13}$ Ibid., p. 226; cf., pp. 142, 227, 253.

${ }^{14}$ Ibid., p. 5

${ }^{15}$ Geuss, The Idea of A Critical Theory (1981), p. 55; cf., pp. 56, 79-80.

${ }^{16}$ Max Weber, The Methodology of the Social Sciences, Translated and Edited by Edward A. Shils and Henry A. Finch (New York: The Free Press of Glencoe, 1949), pp. 11, 14-15, 17-18, 20-22, 24, 33-34, 53-58, 60, 76-78, 80-84, 90, 143-52; Mills, The Sociological Imagination (1959), pp. 129-31, 173-74, 177. See also Mary Hesse, "Theory and Value in the Social Sciences" in Christopher Hookway and Philip Pettit (eds.), Action and Interpretation: Studies in the Pbilosopby of the Social Sciences (Cambridge: Cambridge University Press, 1978), pp. 1-16; and Susan James, The Content of Social Explanation (Cambridge: Cambridge University Press, 1984).

${ }^{17}$ While Bowles and Gintis in the first chapter of Democracy and Capitalism (1986) bracket metatheory, they unabashedly, and appropriately, confess to allowing their moral and political commitments to set the theoretical agenda of their book.

${ }^{18}$ See Mills, The Sociological Imagination (1959), pp. 179-81, 188-92; David Kettler, "The Vocation of Radical Intellectuals," Politics and Society 1 (November, 1970), pp. 23-49; Frank Lentricchia, Criticism and Social Change (Chicago: University of Chicago, 1983), Pp. 2, 6-13, 19, 26, 32, 34-36, 39-40, 50-51; Michael Walzer, The Company of Critics: Social Criticism and Political Commitment in the Twentieth Century (New York: Basic Books, Inc., 1988), chaps. 1 and 13; and Nancy Fraser, Unruly Practices: Power, Discourse, and Gender in Contemporary Social Theory (Minneapolis: University of Minnesota Press, 1989), "Introduction: Apologia For Academic Radicals," pp. 1-13.

${ }^{19}$ Should critical theory address a class-based audience: nonprofessional workers (unionized or not?), the new middle class, the underclass? Should targeted citizens be members of "new social movements" already politically motivated and mobilized? Should critical theorists try to communicate with as wide as a public as possible? The roots of this debate are as old as the conflict between Marx and utopian socialists. See the discussion in Cohen, Class and Civil Society (1982); and Mills, The Sociological Imagination (1959), pp. 184-86, 190-92.

${ }^{20}$ Geuss, Idea of $A$ Critical Theory (1981), pp. 65, 79-81, 85-86, 89-92. As Richard Wolin has argued, these conditions are also psychological insofar as theories "neglect[ing] the sentient and emotional aspects of human action," both in concept and in mode of presentation "result in [a] failure to provide sufficient inducement or motivational inspiration to command the allegiance of its potential addressees." See his "Critical Theory and the Dialectic of Rationalism," New German Critique \#41 (Spring-Summer, 1987), p. 52.

${ }^{21}$ These two questions are not identical. The first is asking about the actual social consequences of the project. The second is asking about the characteristics and quality of the project in relation to its underlying purpose.
22 What I am calling for is a reexamination of what Gouldner called the "sentiments," background" and "domain" assumptions of the project of critical social theory. He called these elements the "infrastructure" of sociology. I am calling for a metatheoretical examination of the infrastructure of critical theory. See Alvin W. Gouldner, The Coming Crisis of Western Sociology (New York: Basic Books, 1970), pp. 7-8, 20-21, 28-54; and idem., The Two Marxisms (New York: Oxford University Press, 1980), pp. 39-44, 58-59, 309-13. Another book, of course, is not a substitute either for an actual realignment of critical theory with its moral and political objectives, or for the strategic thinking, action, and organizational innovation necessary for intellectual integration and for popular enlightenment and political mobilization.

${ }^{23}$ See Mills, The Sociological Imagination (1959), pp. 177-226; James A. Henretta, "Social History and Lived and Written," American Historical Review 84 (December, 1979), pp. 1314-22.

${ }^{24} \mathrm{~A}$ mainstream Marxist approach to the history of capitalism that builds upon Kondratieff long-wave theory is taken by Ernest Mandel in Late Capitalism (London: NLB, 1975) and in Long Waves of Capitalist Development: The Marxist Interpretation (Cambridge: Cambridge University Press, 1980). Another approach, rooted in Marxism, is that of the French "Regulation School." Robert Boyer, a leading member of this group of theorists, surveys their work in The Regulation School: A Critical Introduction, translated by Craig Charney (Cambridge: Cambridge University Press, 1990). Yet a third perspective identifies the phases of capitalism with successive "social structures of accumulation." For purposes of historical periodization, this approach is sympathetic to the long-wave theories of both Kondratieff and Schumpeter. In Segmented Work, Divided Workers: The Historical Transformation of Labor in the United States (Cambridge: Cambridge University Press, 1982), David M. Gordon, Richard Edwards, and Michael Reich build a theory of international capitalist development and then apply it to the U. S. case. Each successive social structure of accumulation can be viewed at a level that abstracts from national peculiarities; but each can also be given a national identity. The American regime at any point in its history is a larger and more complex and decentered totality than its social structure of accumulation. However, any critical social theory addressed to American citizens must recognize the nation's social structure of accumulation as the dynamic core of the regime. What's intriguing about their work is that their use of theory to understand and periodize American labor history materializes at a regime specific level of abstraction. See also David M. Kotz, Terrence McDonough, and Michael Reich, eds. , Social Structures of Accumulation: The Political Economy of Growth and Crisis (Cambridge: Cambridge University Press, 1994).

${ }^{25}$ Three recent comparative and, to some extent, historical analyses could prove useful for the project of critical social theory: Jeffrey A. Hart examines national formations of capitalism in Rival Capitalists: International Competitiveness in the United States, Japan, and Western Europe (Ithaca: Cornell University Press, 1992); David M. Gordon suggests that the organization of work and the relations between labor and capital vary with nationally distinct forms of capitalism in Fat 
and Mean: The Corporate Squeeze of Working Americans and the Myth of Managerial "Downsizing" (New York: Martin Kessler Books, 1996); and Gosta Esping-Andersen in The Three Worlds of Welfare Capitalism (Princeton: Princeton University Press, 1990) differentiates three types of welfare-state regime each of which is linked to an historically and culturally distinct path of development.

${ }^{26}$ In addition to institutional histories of the workplace provided by Gordon, Edwards, and Reich (1982) and Gordon (1996), analysis of the American regime could draw upon institutional histories of the polity (a more inclusive concept than the state), business, law, class formation, education, the "culture industry," the professions, voluntary organizations, an the family. Analysis of the American regime could also profit conceptually and methodologically from James Livingston's integration of political economics and cultural studies in Pragmatism and the Political Economy of Cultural Revolution, 1850-1940 (Chapel Hill: University of North Carolina Press, 1994). Finally, the proposal for integrating the fragmented discipline of American history put forth by Thomas Bender is fully compatible with regime analysis. See Thomas Bender, "Wholes and Parts: The Need For Synthesis in American History," Journal of American History 73 (June, 1986), pp. 120-36.

${ }^{27}$ Karol Edward Soltan and Stephen L. Elkin, eds., The Constitution of Good Societies (University Park: Pennsylvania State University Press, 1996), pp. 186, 187, 197. Soltan and Elkin edited a similar volume in 1993: $A$ Nen Constitutionalism: Designing Political Institutions For a Good Society (Chicago: University of Chicago Press). All the essays in both books contribute to the project of good society analysis.

${ }^{28}$ Bowles and Gintis, Democracy and Capitalism (1986), p. 185.

${ }^{29}$ Jeffrey A. Alexander, "Modern, Anti, Post, and Neo," New Left Review \#210, (March/April, 1995), pp. 68, 70. "In response to continuing social change," Alexander asserts, "generational shifts [among theorists] occur that can make the scientific and ideological efforts of earlier generations seem not only empirically implausible but psychologically shallow, politically irrelevant, and morally obsolete." Ibid., Pp. 7980; cf., 77-79, 81-82, 86, 101.

${ }^{30}$ Fred Block, Postindustrial Possibilities: A Critique of Economic Discourse (Berkeley: University of California Press 1990), p. 2. Block continues: "While there are complex mediations between high social theory and every day 'common sense,' the two are connected in important ways." Presumably these "mediations" require the craftsmanship of professional journalism as well as the pedegogical skills of formal and adult education. See also Steven Best and Douglas Kellner, Postmodern Theory: Critical Interrogations (New York: The Guilford Press, 1991), pp. 259-60; and Krishan Kumar (1995), From Post-Industrial to Post-Modern Society: New Theories of the Contemporary World (Oxford: Blackwell, 1995), pp. vii, 4.

${ }^{31}$ The meaning of "historicism" has become so contested in current academic discourse that some authors refuse to use the term. For my purposes I find historian David A. Hollinger's identification of historicism with "historicity" an acceptable and useful perspective. He writes: "By bistoricity, I mean simply the contingent, temporally and socially situated character of our beliefs and values, of our institutions and practices. When we accept our own historical particularity, we shy away from essentialist constructions of human nature, from transcendentalist arguments about it, and from timeless rules for justifying claims about it. We eschew the Archimedean perspective, and we instead inquire outward from our experience. We practice immanent, rather than transcendental, critique. We confront the insight that truths and rights and obligations become available to us-and thus, it is apparently easy to conclude, come into existence for us-through the operation of historically contingent communities of human beings." David A. Hollinger, "How Wide the Circle of the 'We"' in Scientific Authority \& Tiventieth Century America, edited by Ronald G. Walters (Baltimore: Johns Hopkins University Press, 1997), p. 16.

${ }^{32}$ For a reading of Dewey as an historicist see Koppenberg Uncertain Victory (1986); Antonio, "The Normative Foundations of Emancipatory Theory: Evolutionary Versus Pragmatic Perspectives," (1989). American Journal of Sociology, 94 (January), pp. 721-48.

33 John Dewey, Reconstruction in Philosopby, Enlarged edition (Boston: Beacon Press, [1920] 1957), pp. 188, 189, 200.

${ }^{34}$ Kloppenberg, Uncertain Victory (1986), pp. 101, 107-14, 152, 156, 334-35, 412.

${ }^{35}$ John Dewey, "Need For A Recovery of Philosophy," in Creative Intelligence, by John Dewey et al. (New York: Henry Holt and Company, 1917), p. 65; cf., pp. 45; idem., Reconstruction in Philosopby, enlarged ed. (Boston: Beacon Press, 1920 [1957]), pp. 21, 22, 26; idem., Democracy and Education: An Introduction to the Pbilosophy of Education (New York: The Free Press, 1916), pp. 328-29, 331-32; idem., "Context and Thought," (1931) in Jobn Devey On Experience, Nature, and Action, edited by Richard J. Bernstein (New York: The Liberal Arts Press, 1960) p. 105; idem., The Middle Works, 1899-1924, edited by Jo Ann Boydson (Carbondale: Southern Illinois University Press, 1976-83), IV, p. 36; IX, p. 338, X, p. 47; XII, p. 260, 266, 273-77; idem., The Later Works, 1925-1953, edited by Jo Ann Boydson (Carbondale: Southern Illinois University Press, 1981-92), III, pp. 115-16; VIII, p. 30; XII, p. 274.

${ }^{36}$ Dewey, Reconstruction in Pbilosopby, p. 26. In The Public and Its Problems (1927), Dewey argues that problems become public when citizens become conscious of the negative consequences (often unintended) of social interaction in the economy and other quasi-public spaces, and recognize that solutions require collective action and/or public policy. Despite his criticism of Dewey, Mills' discussion of troubles and issues simply resonates with Dewey's ideas and thetoric. A good example appears in an essay entitled "The Complacent Young Men" (1958) where he writes that there is an "unmet need" for intellectuals "(1) to formulate private troubles out of the vague uneasiness of individuals; (2) to make public issues out of indifference and malaise; [and] (3) to pick up both the uneasiness and the indifference-formulated as troubles and issues_-in problems open to inquiry." See C. Wright Mills, Power, Politics and People (1963), p. 387.

${ }^{37}$ Dewey, "Need For A Recovery of Philosophy" (1917), p. 67.

${ }^{38} \mathrm{H}$. H. Gerth and C. Wright Mills, trans. and eds., From Max Weber: Essays in Sociology (New York: Oxford University Press, 1946), p. 280. Dewey would have 
added the concepts of "habit" and "desire" to Weber's two types of interest and, like Weber, he would have insisted on the social sources of these motivational factors.

${ }^{39}$ John Dewey, Freedom and Culture (New York: Capricorn Press, 1939), pp. 52 , 60-61, 72-63, 123; idem., Later Works, XI, pp. 55-57. Dewey was also concerned about the connections between material and ideal interests: "[T] he habit of separating economic interests from ideal interests affords a typical instance of the too common separation of means and ends with the result that ideals become empty and impotent, while means left to themselves in isolation from service to ends, produce brutal and unjust consequences." Later Works, VIII, p. 85; XI, pp. 62-65.

${ }^{40}$ Gerth and Mills, From Max Weber (1946), p. 281. In Dewey's Quest For Certainty (1929) it is not simply traditional religious conceptions of nature, man, and society that modern science makes obsolete, but also the Newtonian world-view and the political and social theories based on it.

${ }^{41}$ Dewey, Reconstruction In Pbilosopby (1920/1957), p. 26.

${ }^{42}$ Later Works, I, p. 40; VIII, p. 29. Charles S. Peirce and Hans-Georg Gadamer hold similar views.

${ }^{43}$ Later Works, V, pp. 163-64; I, p. 305. In "Authority and Social Change" (1936) Dewey writes of the "foes against which [criticism has] had to make its way: the foes of inertia, of old, long-established traditions and habits - . . all . . entrenched in forms of institutional life that are effulgent with the prestige of time, that are enveloped in the glamour of imaginative appeal and that are crowned, severally and collectively with an emotional halo made of the values that men most prize." Later Works, XI, p. 141.

${ }^{44}$ Ibid., VIII, pp. 29-30.

${ }^{45}$ Ibid., I, pp. 296-301, 304-06, 308, 326; cf., VIII, p. 25; John Dewey, Theory of Valuation in International Encyclopedia of Unified Science, vol. II, number 4, edited by Otto Neurath (Chicago: University of Chicago Press, 1939), pp. 57-58.

${ }^{46}$ Later Works, III, p. 127; cf., Reconstruction In Pbilosopby (1920/1957), pp. 3844.

${ }^{47}$ Later Works, III, p. 127; cf., Democracy and Education (1916), p. 83. Looking at the world in the aftermath of the First World War, Dewey wrote in his Gifford Lectures, Quest For Certainty (1929): "Conditions and forces that dominate in actual fact the modern world have not attained any coherent intellectual expression of themselves." (p. 77; cf., 312-13). Of urgent concern was the exploration of the meaning-what Weber, echoing Nietzche's Genealogy of Morals, called "cultural significance" —of modern science. In "Context and Thought" (1931) Dewey said "The place of science in life, the place of its peculiar subject matter in the wider scheme of materials we experience, is a more ultimate function of philosophy to [discern] than is any self-contained reflection upon science as such." (p. 108) The search for meaning should replace the quest for certainty. In this respect, philosophy cooperates with science appropriately construed: "All knowledge, all science, ... aims to grasp the meaning of objects and events. This process always consists in taking them out of their apparent brute isolation as events, and finding them to be part of some larger whole suggested by them, which, in turn, accounts for, explains, interprets them; i.e., renders them significant." How We Think in Middle Works, VI, p. 272; see also 273-85. All of this is background for a bold statement in the essay "Philosophy and Civilization" (1927): "Meaning is wider in scope as well as more precious in value than is truth, and philosophy is occupied with meaning rather than with truth." Later Works, III, p. 4; cf., 5, 8-9; see also Middle Works, XI, pp. 43-44, 47.

${ }^{48}$ Later Works, p. 130; cf., 127-28, 131; Reconstruction in Pbilosopby (1920/ 1957), pp. 26-27. This hermeneutical dimension of Dewey's philosophy is clearly stated in "Education and New Social Ideals," a radio speech delivered in 1936: "The point I want most to emphasized is that fundamentally and inherently the social ideals that demand a change in education are not new. They are a new version of the very same ideals ['democracy,' 'liberty,' 'equality'] that inspired the Declaration of Independence one hundred and sixty years ago. A new version is needed because of the enormous social changes that have taken place in this period of time. ... [The new version is] new only in relation to the method and means demanded in order that the ideals may be realized." Later Works, XI, p. 167; cf., pp. 29-30, 35-38, 168, 292, 370-71; VIII, pp. 55, 57-58, 65, 82-84.

${ }^{49}$ Later Works, I, p. 306. Contemporary philosophy is to take over a role previously played by theology. Philosophy as a "generalized medium of intercommunication" is powerfully restated in the concluding pages of Quest For Certainty (1929) and then again in a short piece entitled "Philosophy" published in Encyclopedia of the Social Sciences (1934): "There is a kind of music of ideas that appeals, apart from any question of empirical verification, to the minds of thinkers, who derive emotional satisfaction from an imaginative play synthesis of ideas obtainable by them in no other way. The objective side of this phenomenon is the role of philosophy in bringing to a focus of unity and clarity the ideas that are at work in a given period more or less independently of one another, in separate cultural streams. . . . The significance of such synthesizing ideas is more or less independent of verifiabilty. The human mind, taken collectively, experiences the need of holding itself together, and during periods of rapid influx of new materials and the inception of new and diverging tendencies, accomplishes this task by means of comprehensive speculative ideas." Later Works, VIII, p. 38. Finally, this theme plays a role in Dewey's political theory: “ The problem of creat[ing a] genuine democracy cannot be successfully dealt with in theory or in practice save as we create intellectual and moral integration out of present disordered conditions." Freedom and Culture (1939). P. 49.

${ }^{50}$ Quest For Certainty (1929), p. 43; cf., pp. 40, 44, 47-48, 70-71, 76-77. The phrase is used again as a chapter heading and expounded in Individualism, Old and New (1929-30) chap. 7 in The Later Works, V, pp. 99-110. This crisis in modern culture was also a "crisis in liberalism;" See Liberal and Social Action (1935) in chap. 2 of The Later Works, XI, pp. 23-40.

${ }^{51}$ Later W'orks, V, p. 143; Public and its Problems (1927), pp. 200-03; Freedom and Culture (1939), pp. 52, 65, 72-73, 101-02, 128. As important as the concept of "community of inquiry" is for Dewey's theory of democracy, it is important to 
recognize that both the concept and the theory are rooted in Dewey's philosophical natururalism, ethics, and critical interpretation and appropriation of America's political traditions. See Robert B. Westbrook, Jobn Dewey and American Democrac (Ithaca: Cornell University Press, 1991) and Matthew Festenstein, Pragmatism and Political Theory (Chicago: University of Chicago Press, 1997).

${ }^{52}$ Later Works, VIII, p. 74; cf., pp. 70, 72; and ibid., V, p. 115; XIII, p. 321.

53 Ibid., XI, p. 231, 234-37; VIII, p., 69, 73; Public and its Problems (1927), pp. 154-55

${ }^{54}$ Ibid., VIII, pp. 48, 52.

55 Ibid., VIII, pp., 72-73, 82-84; XI, pp. 217-19, 231; Public and its Problems (1927), 143-44, 146; Freedom and Culture (1939), pp. 4-5, 50-51, 175-76.

${ }_{56}$ Later Works, VIII, pp. 45-46, 49-53, 80-81; XI, pp. 167-68, 217-22, 225, 236-37, 368-71, 415-16; Democracy and Education (1916), 87, 122, 329, 331; Public and Its Problems (1927), pp. 26, 39, 143-44, 156, 211-19; Freedom and Culture (1939), pp. 4-5, 63-64, 123-25, 155-63.

57 The most explicit evidence of Dewey's affinity for Jefferson's participatory republicanism appears in Freedom and Culture (1939). To this evidence should be added his Lincoln-like belief in the moral superiority of the Declaration of Independence over the Federal Constitution not merely as a founding document of the nation, but also as an authoritative statement of definitive national ideals. Freedom and Culture (1939), pp. 45, 40, 52, 54, 155-65; Later Works, VIII, pp. 49-53; XI, pp. 64, 167-68, 368-71; "Presenting Thomas Jefferson," in The Living Thoughts of Thomas Jefferson, ed. John Dewey (New York: Longmans, Green and Co., 1940), pp. 1-30; and idem., "Thomas Jefferson and the Democratic Faith," Virginia Quarterly Review 16(January, 1940), pp. 1-13. For a recent analysis of Jefferson's political philosophy that corroborates Dewey's interpretation, see Richard K. Matthews, The Radical Politics of Thomas Jefferson (Lawrence: University of Kansas Press, 1986).

${ }^{58}$ Later Works, XI, pp. 167-68; VIII, pp. 46, 80-81.

${ }^{59}$ Dewey rejected the idea of historical inevitability: "Commitment to inevitability is always the fruit of dogma; intelligence does not pretend to know save as a result of experimentation, the opposite of a preconceived dogma." Later Works, XI, p. 55; cf., Freedom and Culture (1939), pp. 151, 173; Later Works, VIII, p. 70.

${ }^{60}$ Later Works, VIII, p. 81; XI, pp. 44-45, 296-99.

${ }^{61}$ The closest Dewey comes to regime theory and analysis is in his last book of political philosophy, Freedom and Culture (1939). Both descriptive and normative tracks are interwoven in the book, but its purpose is to provide neither an extensive account of the existing regime nor a utopian blueprint of a desirable future. His purpose is to pose the problem of what kind of society or "culture" - understood a set of interacting and mutually sustaining institutions and traditions-is necessary for the creation and continuing reproduction of democracy and freedom. "For the successful working of democratic [institutions] ... and for individuals to be free, we must see to it that suitable [cultura] conditions exist." (pp. 49, 34) Drawing upon his reading of anthropology his argument is that we need a broad concept of culture-his concept of regime-to even pose and examine the many dimensions of the problem: "The state of culture is a state of interaction of many factors, the chief of which are law and politics, industry and commerce, science and technology, the arts of expression and communication, and of morals, or the values men prize and the ways in which they evaluate them; and finally, though indirectly, the system of general ideas used by men to justify and to criticize the fundamental conditions under which they live, their social philosophy." (p. 23) As necessary first steps in understanding and responding to the problem of creating and sustaining a democratic way of life, both descriptive cultural (or regime) analysis at a concrete level of historical specificity and good society thinking at the level of institutional design and reconstruction is required.

${ }^{62}$ Middle Works, XI, pp. 46-47 (my emphasis). "Such a vision [of a collective good life]," Dewey states elsewhere, "is preliminary to action which will develop the new society." Later Works, VIII, p. 72.

${ }^{63}$ Ibid., p. 81. Essays where Dewy draws the distinction between democracy as a way of life and democratic government include "Democracy and Educational Administration" (1937) in Later Works, XI, pp. 217-25, and "Creative DemocracyThe Task Before Us" in Ibid., XIV, pp. 224-30. This distinction is also a central theme of both The Public and Its Problems (1927) and Freedom and Culture (1939). See also Democracy and Education (1916), p. 87 and Later Works, VIII, pp. 49-50; XI, pp. 236-37, 416-17. A helpful article by John J. Stuhr entitled "Democracy as a Way of Life" appears in John J. Stuhr, ed., Philosopby and the Reconstruction of Culture: Pragmatic Essays after Dewey. (Albany: State University of New York Press, 1993), pp. 37-57.

${ }^{64}$ Michael Walzer, Spheres of Justice: A Defense of Pluralism and Equality (New York: Basic Books, Inc., 1983). P. 318.

${ }^{65}$ Later Works, XI, Pp. 45-61, 258-60, 285-95, 489-95; Freedom and Culture (1939), pp. 68-73.

${ }^{6}$ In a 1937 review of Walter Lippmann's An Inquiry Into The Principles of the Good Society in which Dewey defends liberal socialism against the charge of being another form of authoritarian socialism, he states: "That a free and open market for the consumer would be the economic mark of a free society I no more doubt than I doubt that a free society would be one of equal reciprocal rights and duties." Later Works, XI, p. 491. Richard Rorty's own position captures Dewey's view: "There is nothing sacred about either the free market or about central planning: the proper balance between the two is a matter of experimental tinkering." Richard Rorty, "Thugs and Theorists, A Reply to Bernstein," Political Theory, 15 (November, 1987), p. 565.

${ }^{67}$ For Dewey's critique of orthodox Marxism see Freedom and Culture (1939), pp. $12-14,16-18,23-29,32-34,39-40,51-53,73-78,83-87,93-100,105-06$, and Later Works, XI, pp. 413-14; and for his aversion to authoritarian socialism see ibid., p. 288; V, p. 87; XIII, pp. 316-17; XIV, pp. 91-94. In two recent articles Thelma Z. Levine judges Dewey's position a variation of Marxism, refuses to recognize (as Dewey did) a socialist alternative to the bureaucratic socialism of the Soviet Union, and argues that the collapse of the latter, in effect, repudiates Dewey's normative projections. See Thelma Z. Levine, "American Philosophy, Socialism, and the 
Contradictions of Modernity," in Pbilosopby and the Reconstruction of Culture: Pragmatic Essays after Dewey, ed. John J. Stuhr. (Albany: State University of New York Press, 1993), pp. 1-15; and "The Contemporary Significance of the American Philosophic Tradition: Lockean and Redemptive," in Reading Dewey: Interpretations for a Postmodern Generation, ed. Larry A. Hickman. (Bloomington: Indiana University Press), pp. 21730.

${ }^{68}$ Ibid., p. 94; cf., XI, pp. 140-41, 144; Freedom and Culture (1939), pp. 68-73.

${ }^{69}$ Later Works, XI, pp. 221, 225; XIV, pp. 224-30.

${ }^{70}$ Individualism, Old and New (1929-30), p. 89. Robert Westbrook writes: "For a philosopher who put democratic ideals at the center of his thinking, Dewey had surprisingly little to say about democratic citizenship ... [or] the demanding conditions he set for [the] the realization [of these ideals]." Westbrook, Jobn Dewey and American Democracy (1991), pp. 317, 318.

${ }^{11}$ The ideal represents "intelligently thought-out possibilities of the existent world which may be used as methods for making over and improving it." Reconstruction in Pbilosophy (1920 [1957]), p. 122; cf., pp. 117-18, 121-24. Similarly, in Individualism, Old and New (1929-30) Dewey wrote: "Ideals express possibilities; but they are genuine ideals only in so far as they are possibilities of what is now moving. Imagination can set them free from their encumbrances and project them as a guide in attention to what now exists. But save as they are related to actualities, they are pictures in a dream." p. 112. See also The Quest For Certainty (1929), pp. 299-300, 302-03, 310-13; Theory of Evaluation (1939), pp. 39-40, 42-43, 49; Middle Works, XIV, pp. 161, 162; and Later Works, III, pp. 129-31; VIII, p. 46.

${ }_{72}$ If we substitute "democratic socialism" for "commercial republic," this passage from a recent exercise in normative regime analysis by Stephen L. Elkin would be endorsed by Dewey: "Whether we can more fully realize an American commercial republic depends very much on our institutional inheritance: what the founders of this republic bequeathed to us as well as what succeeding generations have put into place. Thus, we can reform ourselves-but not just as we please, for there is no 'we' apart from the existing institutions that form us as a people." (my emphasis) Stephen L. Elkin, "The Constitution of a Good Society: The Case of the Commercial Republic," in Solton and Elkin eds., The Constitution of Good Societies (1996), p. 143.

${ }^{73}$ The two essays are "The Socio-Economic Situation of Education" (1933) and "The Underlying Philosophy of Education" (1933). Both appear in The Later Works, volume 8. The quotation is from pages 44-45. See also pp. 82-84. Readers of Dewey should keep in mind that he considered "a philosophy of education may ... truly be said to be general philosophy formulated with particular reference to its social office." Ibid., p. 84.

${ }^{74}$ Ibid., pp. 46, 48-49, 52-53, 64-66, 68-69, 97.

75 The "Achilles heel" of laissez-faire liberalism, according to Dewey, is the belief that "the effective liberty and cultural development of the individuals that constitute society . . . [can be] established by an unplanned and external convergence of separate individuals, each of whom is bent on personal private advantage." Ibid., XI, p. 40.

${ }^{76}$ Ibid., p. 49; cf., pp. 48, 55-57, 75-76, 84, 87, 89.

${ }^{77}$ Ibid., pp. 101-04; cf., ibid., XI, pp. 221, 224-25; Democracy and Education (1916), p. 85.

${ }^{78}$ Later Works, VIII, p. 73; Freedom and Culture (1939), p. 72; cf., p. 93; Later Works., V, pp. 84, 89. Dewey uses various labels for the existing regime: "a pecuniary culture" (ibid., pp. 49, 55-56); "a money culture" (ibid., p. 55); "a regime of highly centralized finance and industry" (ibid., XI, p. 252); "finance capitalism" (ibid., Pp. 296, 371); and "private profit economic system" (ibid., p. 493) among others.

${ }^{79}$ Ibid., p. 297.

8n Ibid., pp. 17-19,21, 24

${ }^{81}$ Ibid., pp. 42-43, 62-63; V, pp. 86-87, 105-06; Freedom and Culture (1939), p. 143.

${ }^{82}$ Later Works, V, p. 69; XIII, 309-15.

${ }^{83}$ Middle Works, XI, p. 44. The fact that social philosophy begins with "passionate desires ... hopes ... [and] moral convictions is, according to Dewey, a principal reason for divergent philosophical or theoretical positions. Translating these desires, hopes, and convictions into "an interpretation of man and nature on the basis of some program of comprehensive aims and policies" produces different meanings for core values like democracy, liberty, and justice. "Relativists and absolutists, radicals and conservatives, spiritualists and materialists, differ primarily in their systems of value and their strictly intellectual differences follow logically. . . In spite of conflicts[, however,] philosophy serves the purpose of clarifying the source of opposition and the problems attendant upon it; while with some problems articulation and clarification are more significant than formal solution." Later Works, VIII, pp. 25, 27; cf., 26, 28-30; VII, pp. 176-78.

${ }^{84}$ We get an idea of the nature of the "social liberalism" that animates Dewey's attraction to a democratic socialist regime in this passage from Liberalism and Social Action (1935): [C]ivilization is faced with the problem of uniting the changes that are going on into a coherent pattern of social organization. The liberal spirit is marked by its own picture of the pattern that is required: a social organization that will make possible effective liberty and opportunity for personal growth in mind and spirit in all individuals. Its present need is recognition that established material security is a prerequisite of the ends which it cherishes, so that, the basis of life being secure, individuals may actively share in the wealth of cultural resources that now exist and may contribute, each in his own way, to their further enrichment. . . . Organized planning put into effect for the creation of an order in which industry and finance are socially directed in behalf of institutions that provide the material basis for the cultural liberation and growth of individuals, is now the sole method of social action by which liberalism can realize its professed aims." Later Works, XI, pp. $41,40$.

${ }^{85}$ Ibid., V, pp. 163-65; VIII, pp. 35-39. Dewey links his practice of social philosophy and the broad scope of its subject matter to the scope of "moral 